Article

\title{
Dose and Exposure Time-Dependent Renal and Hepatic Effects of Intraperitoneally Administered Fumonisin $B_{1}$ in Rats
}

\author{
András Szabó 1,2,3,*®D, Judit Szabó-Fodor ${ }^{1}$, Mariam Kachlek ${ }^{2} \mathbb{D}$, Miklós Mézes ${ }^{1,4}$, \\ Krisztián Balogh ${ }^{1,4}$, Róbert Glávits ${ }^{5}$, Omeralfaroug Ali ${ }^{2} \mathbb{D}$, Yarsmin Yunus Zeebone ${ }^{2}$ \\ and Melinda Kovács 1,2 \\ 1 MTA-KE-SZIE Mycotoxins in the Food Chain Research Group, Kaposvár University, Guba S. u. 40., \\ 7400 Kaposvár, Hungary; szabo.fodor.judit@gmail.com (J.S.-F.); mezes.miklos@mkk.szie.hu (M.M.); \\ balogh.krisztian@mkk.szie.hu (K.B.); kovacs.melinda@ke.hu (M.K.) \\ 2 Faculty of Agricultural and Environmental Sciences, Kaposvár University, Guba S. 40., \\ 7400 Kaposvár, Hungary; mariamkachlek@gmail.com (M.K.); vomer2011@gmail.com (O.A.); \\ yasminzeebone@yahoo.com (Y.Y.Z.) \\ 3 Somogy County Kaposi Mór Teaching Hospital, Dr. József Baka Diagnostical, Oncoradiological, \\ Research and Educational Center, Guba S. u. 40., 7400 Kaposvár, Hungary \\ 4 Faculty of Agricultural and Environmental Sciences, Department of Nutrition, Szent István University, \\ Páter K. u. 1., 2013 Gödöllő, Hungary \\ 5 Autopsy Ltd., Telepes u. 42., 1147 Budapest, Hungary; glavits.robert.dr@gmail.com \\ * Correspondence: szan1125@freemail.hu; Tel.: +36-82-505-800
}

Received: 15 October 2018; Accepted: 7 November 2018; Published: 9 November 2018

\begin{abstract}
Male Wistar rats were treated intraperitoneally (i.p.) with fumonisin $\mathrm{B}_{1}\left(\mathrm{FB}_{1} ; 0,20,50\right.$ and $100 \mathrm{mg} / \mathrm{kg}$ dietary dose equivalent) for 5 and 10 days $(n=24-24$ in each setting) to gain dose- and time-dependent effects on antioxidant status and oxidative stress response, clinical chemical endpoints and liver, kidney and lung histopathology and lymphocyte damage (genotoxicity). $\mathrm{FB}_{1}$ decreased feed intake, body weight gain and absolute liver weight, irrespective of the toxin dose. Relative kidney weight increased in the 10-day setting. Linear dose response was found for plasma aspartate aminotransferase, alanine aminotransferase, total cholesterol, urea and creatinine, and exposure time-dependence for plasma creatinine level. The latter was coupled with renal histopathological findings, tubular degeneration and necrosis and the detachment of tubular epithelial cells. The pronounced antioxidant response (reduced glutathione accretion, increasing glutathione peroxidase activity) referred to renal cortical response (5-10 days exposure at 50-100 ppm $\mathrm{FB}_{1}$ ). Hepatic alterations were moderate, referring to initial phase lipid peroxidation (exposure time dependent difference of conjugated diene and triene concentrations), and slight functional disturbance ( $\uparrow$ total cholesterol). Lymphocyte DNA damage was moderate, supporting a mild genotoxic effect of $\mathrm{FB}_{1}$.
\end{abstract}

Keywords: fumonisin $\mathrm{B}_{1}$; rat; dose-dependence; hepatotoxicity; nephrotoxicity; genotoxicity

Key Contribution: Intraperitoneally administered fumonisin $B_{1}$ was found to compromise growth, feed intake and to induce linear dose response for plasma aspartate aminotransferase (AST), alanine aminotransferase (ALT), total cholesterol, urea and creatinine, in male rats. Renal effects were pronounced, consisting of tubular degeneration and pronounced antioxidant response, while hepatic influencement was moderate. 


\section{Introduction}

Fumonisins (FUMs) are mycotoxins produced predominantly by Fusarium verticillioides and Fusarium proliferatum. The 28 FUM analogues that have been characterized since 1988 can be divided into four main groups identified as fumonisin A, B, C, and P series [1]. Among the four groups (FA, FB, FC and FP), the toxicologically most important compounds are the $B$ analogues. They are hydrocarbon long-chain aminopolyols with two tricarballylic acid side chains. Fumonisin $\mathrm{B}_{1}\left(\mathrm{FB}_{1}\right)$ is the most important representative of FBs [2]. In most cases, in field samples, $\mathrm{FB}_{1}$, fumonisin $\mathrm{B}_{2}\left(\mathrm{FB}_{2}\right)$ and fumonisin $\mathrm{B}_{3}\left(\mathrm{FB}_{3}\right)$ contributed to approximately $70 \%, 20 \%$ and $10 \%$ of $\mathrm{FBs}$, respectively [2]. $\mathrm{FB}_{1}$ is generally found in the highest concentrations in maize and maize-based products [3,4].

A series of studies reported the occurrence of $\mathrm{FB}_{1}$ and $\mathrm{FB}_{2}$ in maize and products thereof in different European countries [5-9]. Although occurrence is widespread, concentration levels ranged only between 0.2 and $2 \mathrm{mg} / \mathrm{kg}$, with generally higher levels in unprocessed materials.

In vivo studies on the toxicity of $\mathrm{FB}_{1}$ indicate that kidneys and liver are the main target organs. $\mathrm{FB}_{1}$ is the causative factor of equine leucoencephalomalacia [10], porcine pulmonary oedema syndrome [11] and hepatocellular carcinoma in rats [12]. $\mathrm{FB}_{1}$ is possibly carcinogenic for humans; it has been classified as a possible carcinogen (group 2B) [13]. All FUMs are highly polar and water soluble compounds. Structurally, the fumonisin backbone resembles the sphingoid bases sphinganine (Sa) and sphingosine (So) especially with the amino and hydroxy groups in positions $\mathrm{C} 2$ and $\mathrm{C} 3$. The key event is fumonisin-mediated inhibition of ceramide synthases (CerS). Inhibition of CerS results in the disruption of sphingolipid metabolism and, as a consequence, alterations in other lipid pathways. FUMs are regarded as structural analogues of free sphingoid bases and they competitively inhibit CerS, a group of key enzymes in the biosynthesis of ceramide and more complex sphingolipids [14].

Toxic substances generally negatively affect the overall health status of an organism, sometimes inducing direct oxidative stress. Focusing specifically on $\mathrm{FB}_{1}$, results gained so far on rodents suggest induction of oxidative stress directly or indirectly. In mice, in the spleen, exposure to the $\mathrm{FB}_{1}$ led to increased caspase-3 activity, lipid peroxidation, and interleukin-10 (IL) and IL-4 mRNA levels, but decreased reduced glutathione (GSH) content and down-regulated expression of glutathione peroxidase (GSPHx) and superoxide dismutase, and of interferon- $\gamma$ and tumor-necrosis factor $\alpha$ mRNA [15]. In our earlier studies, high dose (50 ppm), but short exposure (5 days) in rats depleted hepatic GSH and induced lipid peroxidation (malondialdehyde, MDA), without activating the enzymatic defense [16]. In rabbits, the hepatic lipid peroxidation was minimal, as assessed by GSH, GSHPx and MDA, after feeding $10 \mathrm{ppm} \mathrm{FB}$ for 4 weeks [17]. The nature of $\mathrm{FB}_{1}$-induced oxidative stress is likewise acute. We were able to assess augmented lipid peroxidation in a short-term treatment [16], which was not present after prolonged $\mathrm{FB}_{1}$ exposure [17]. A typical form of this adaptation has already been reported [18] where, in vitro, primary hepatocytes provided increased membrane lipid levels of C18:1 n9 (oleic acid) and reduced polyunsaturated fatty acid (PUFA) niveau, as a means to provide selective resistance to $\mathrm{FB}_{1}$-induced oxidative stress, and even apoptosis resistance. Besides in vitro results, recent studies reported that the generation of reactive oxygen species (ROS) and oxidative stress was closely related to $\mathrm{FB}_{1} \mathrm{~s}$ immunotoxic effect [19]. The most comprehensive review on the oxidative stress-mediated toxicity of $\mathrm{FB}_{1}$ has reported DNA damaging and genotoxic effects, as well as lipid peroxidation, all via a ROS-mediated manner [20]; however, as a limitation, most studies merely ascertained the toxic effect, but dose-response analysis is rare.

In this study, male Wistar rats were treated intraperitoneally (i.p.) with varying doses of $\mathrm{FB}_{1}$ $(0,20,50$ and 100 ppm dietary dose equivalent) over periods of 5 and 10 days to ascertain the doseand time-dependent effect of $\mathrm{FB}_{1}$ in mediating oxidative stress. 


\section{Results}

\subsection{Feed Intake, Body and Organ Weights}

All toxin-treated groups provided lower daily feed intake values from experimental days 3 and 4 onwards. Increasing exposure $(20,50,100 \mathrm{ppm})$ decreased feed intake to 68,54 and $42 \%$ until day 5 and to 51,45 and $25 \%$ by day 10, respectively, as compared to the control. As a strongly relevant factor, the body weight (BW) gain showed a similar pattern in the control and treated groups, namely all toxin-treated groups showed BW loss, if expressed in a cumulative manner, for the 5 and the 10 experimental days (Table 1). The absolute BW at the end of the treatments was lower in all toxin-treated groups in the 5-day setting, as compared to the control, while below-control values were found for the 50 and the 100 ppm treatments in the 10-day study.

Table 1. Body weight (BW), absolute and relative organ weight of the rats in study (data are means \pm standard deviation (SD) of 6 individuals/group).

\begin{tabular}{|c|c|c|c|c|c|}
\hline Group & Days in Treatment & Control & $20 \mathrm{ppm}$ & $50 \mathrm{ppm}$ & $100 \mathrm{ppm}$ \\
\hline \multirow{2}{*}{ BW_initial (g) } & 5 & $326.7 \pm 15.2$ & $323.6 \pm 10.7$ & $324.0 \pm 9.60$ & $331.1 \pm 9.93$ \\
\hline & 10 & $325.5 \pm 13.9$ & $329.4 \pm 6.9$ & $336.9 \pm 15.6$ & $329.8 \pm 20.6$ \\
\hline \multirow{2}{*}{ BW_final (g) } & 5 & $346.7 \pm 14.6^{b}$ & $316.9 \pm 17.5^{\mathrm{a}}$ & $315.5 \pm 17.2^{\mathrm{a}}$ & $308.1 \pm 15.1^{\mathrm{a}}$ \\
\hline & 10 & $368.0 \pm 11.6^{b}$ & $321.8 \pm 28.5^{\mathrm{ab}}$ & $283.4 \pm 36.1^{\mathrm{a}}$ & $270.7 \pm 47.9^{a}$ \\
\hline \multirow{2}{*}{ BW_gain (g) } & 5 & $19.9 \pm 2.29^{c}$ & $-6.73 \pm 7.97^{b}$ & $-8.55 \pm 7.95^{b}$ & $-23 \pm 10.7^{a}$ \\
\hline & 10 & $42.5 \pm 13.4^{c}$ & $-7.58 \pm 30.0^{b}$ & $-53.5 \pm 29.0^{a b}$ & $-59.1 \pm 34.1^{a}$ \\
\hline \multirow{2}{*}{ liver $(\mathrm{g})$} & 5 & $14.1 \pm 1.18^{b}$ & $10.1 \pm 1.37^{a}$ & $10.1 \pm 0.87^{a}$ & $8.97 \pm 0.41^{a}$ \\
\hline & 10 & $15.2 \pm 1.14^{b}$ & $9.12 \pm 2.55^{\mathrm{a}}$ & $7.83 \pm 1.66^{\mathrm{a}}$ & $7.45 \pm 1.41^{\mathrm{a}}$ \\
\hline \multirow{2}{*}{ rel. liver (\%) } & 5 & $4.07 \pm 0.28^{b}$ & $3.15 \pm 0.29^{a}$ & $3.22 \pm 0.21^{a}$ & $2.92 \pm 0.08^{a}$ \\
\hline & 10 & $4.12 \pm 0.22^{b}$ & $2.92 \pm 0.52^{\mathrm{a}}$ & $2.73 \pm 0.32^{a}$ & $2.80 \pm 0.19^{a}$ \\
\hline \multirow{2}{*}{ kidney (g) } & 5 & $2.33 \pm 0.19$ & $2.07 \pm 0.12$ & $2.27 \pm 0.27$ & $2.07 \pm 0.16$ \\
\hline & 10 & $2.47 \pm 0.21 \mathrm{ab}$ & $2.42 \pm 0.22 \mathrm{ab}$ & $2.30 \pm 0.22^{a}$ & $2.77 \pm 0.39^{b}$ \\
\hline \multirow{2}{*}{ rel. kidney (\%) } & 5 & $0.68 \pm 0.04$ & $0.63 \pm 0.05$ & $0.72 \pm 0.10$ & $0.67 \pm 0.08$ \\
\hline & 10 & $0.67 \pm 0.05^{a}$ & $0.78 \pm 0.15^{a}$ & $0.83 \pm 0.10^{a b}$ & $1.05 \pm 0.21^{b}$ \\
\hline \multirow{2}{*}{ lung (g) } & 5 & $2.35 \pm 0.28^{b}$ & $1.82 \pm 0.40^{a}$ & $1.60 \pm 0.22^{\mathrm{a}}$ & $1.52 \pm 0.12^{a}$ \\
\hline & 10 & $1.73 \pm 0.14$ & $1.60 \pm 0.13$ & $1.55 \pm 0.14$ & $1.58 \pm 0.13$ \\
\hline \multirow{2}{*}{ rel. lung. \% } & 5 & $0.68 \pm 0.07^{b}$ & $0.57 \pm 0.13^{\mathrm{ab}}$ & $0.51 \pm 0.07^{a}$ & $0.49 \pm 0.04^{a}$ \\
\hline & 10 & $0.47 \pm 0.04^{a}$ & $0.52 \pm 0.04^{a b}$ & $0.55 \pm 0.06^{\mathrm{ab}}$ & $0.60 \pm 0.07^{b}$ \\
\hline
\end{tabular}

a, b: small uppercase letters indicate significant difference $(p<0.05)$ between means of one row. Bold number pairs indicate significant difference $(p<0.05)$ between 5 and 10-day treatment data.

The absolute liver weight and, similarly, the relative liver weight was higher in the control animals in both treatments ( 5 and 10 days), as compared to all toxin-treated groups, irrespective of the dose (Table 1).

Comparing the exposure-time dependent differences, the group mean values between 5 and 10 days in case of absolute liver weight were different in the 50 and the 100 ppm treatments (Table 1 , bold data pairs).

The absolute kidney weight was not providing dose-related differences in the 5-day treatment, while in the 10-day setting the 50 ppm group had significantly lower values as with the 100 ppm one. The relative kidney weight was the highest in the 100 ppm animals, as compared to the control and the 20 ppm in the 10-day treatment.

Kidney absolute and relative weight was different between the 5- and 10-day treatments in the 20 and the 100 ppm cases (Table 1, bold data pairs).

The absolute lung weight was lower in all toxin treated groups in the 5-day treatment, as compared to the control, while in the 10-day setting difference was not found. The relative lung weight of the control was significantly lower, as compared to the $100 \mathrm{ppm}$ animals on day 10 .

Comparing the 5- and 10-day treatments, the absolute lung weight was different in the control group, while the relative weight was different in the control, the 50 and the 100 ppm settings (Table 1). 


\subsection{Blood Clinical Chemistry}

Blood plasma data determined, along with the inter-group differences are summarized in Table 2.

Table 2. Alterations in serum biochemical parameters study (data are means $\pm S D$ of 6 individuals/group) (AST: aspartate aminotransferase, ALT: alanine aminotransferase).

\begin{tabular}{|c|c|c|c|c|c|}
\hline $\begin{array}{c}\text { Serum } \\
\text { Parameters }\end{array}$ & Days in Treatment & Control & $20 \mathrm{ppm}$ & $50 \mathrm{ppm}$ & 100 ppm \\
\hline \multirow{2}{*}{ AST (IU/L) } & 5 & $181.0 \pm 19.8^{\mathrm{a}}$ & $553.3 \pm 116.2^{b}$ & $570.0 \pm 54.0^{b}$ & $691.5 \pm 189.7^{b}$ \\
\hline & 10 & $170.5 \pm 16.7^{\mathrm{a}}$ & $406.0 \pm 171.4^{\mathrm{ab}}$ & $736.8 \pm 432.8^{b c}$ & $1028.0 \pm 418.0^{c}$ \\
\hline \multirow{2}{*}{$\operatorname{ALT}(\mathrm{IU} / \mathrm{L})$} & 5 & $46.2 \pm 5.27^{\mathrm{a}}$ & $128 \pm 36.72^{b^{*}}$ & $208.8 \pm 29.6^{c^{*}}$ & $205.5 \pm 52.7^{c^{*}}$ \\
\hline & 10 & $43.2 \pm 4.17^{a}$ & $126.7 \pm 29.47^{a b^{*}}$ & $202.8 \pm 102.5 b^{*}$ & $248.3 \pm 81.3^{c^{*}}$ \\
\hline \multirow{2}{*}{$\begin{array}{l}\text { Total protein } \\
(\mathrm{g} / \mathrm{L})\end{array}$} & 5 & $57.0 \pm 1.79^{a}$ & $58.2 \pm 4.17^{\mathrm{a}}$ & $62.8 \pm 1.92^{b}$ & $59.3 \pm 1.97^{a b}$ \\
\hline & 10 & $58.8 \pm 1.47$ & $57.5 \pm 3.62$ & $59.2 \pm 2.93$ & $60.5 \pm 1.76$ \\
\hline \multirow{2}{*}{ Albumin (g/L) } & 5 & $32.7 \pm 0.52^{a}$ & $33.2 \pm 1.94 \mathrm{ab}$ & $35.0 \pm 1.22^{b}$ & $33.5 \pm 1.05^{\mathrm{ab}}$ \\
\hline & 10 & $33.0 \pm 0.63$ & $33.5 \pm 1.38$ & $34.3 \pm 1.63$ & $34.0 \pm 1.26$ \\
\hline \multirow{2}{*}{$\begin{array}{l}\text { Glucose } \\
(\mathrm{mmol} / \mathrm{L})\end{array}$} & 5 & $8.87 \pm 1.15^{c}$ & $6.43 \pm 1.92^{b}$ & $4.32 \pm 0.61^{\mathrm{a}}$ & $4.95 \pm 0.64^{\mathrm{ab}}$ \\
\hline & 10 & $7.15 \pm 1.23^{b}$ & $6.52 \pm 2.25^{a b}$ & $4.13 \pm 1.01^{\mathrm{a}}$ & $4.55 \pm 0.92^{a}$ \\
\hline \multirow{2}{*}{$\begin{array}{l}\text { Total Chol. } \\
(\mathrm{mmol} / \mathrm{L})\end{array}$} & 5 & $2.60 \pm 0.3^{a}$ & $4.63 \pm 0.63^{a b}$ & $5.30 \pm 0.45^{\mathrm{ab}}$ & $6.43 \pm 0.83^{b}$ \\
\hline & 10 & $2.38 \pm 0.15^{\mathrm{a}}$ & $4.43 \pm 0.52^{b}$ & $5.18 \pm 0.91^{\mathrm{b}}$ & $5.92 \pm 1.58^{b}$ \\
\hline \multirow{2}{*}{ Urea $(\mathrm{mmol} / \mathrm{L})$} & 5 & $8.85 \pm 0.53^{a}$ & $10.1 \pm 1.62^{a^{*}}$ & $10.5 \pm 0.86^{a b^{*}}$ & $12.7 \pm 2.11^{b^{*}}$ \\
\hline & 10 & $8.42 \pm 0.35^{a}$ & $12.2 \pm 5.18^{a^{*}}$ & $13.0 \pm 5.12^{a b^{*}}$ & $22.9 \pm 11.1^{b^{*}}$ \\
\hline \multirow{2}{*}{$\begin{array}{c}\text { Creatinine } \\
\text { (micromol/L) }\end{array}$} & 5 & $30.3 \pm 4.23^{a}$ & $47.2 \pm 8.3^{b}$ & $57.0 \pm 7.78^{b c *}$ & $64.5 \pm 7.4^{c^{*}}$ \\
\hline & 10 & $26.3 \pm 1.63^{a}$ & $56.2 \pm 12.6^{b^{*}}$ & $60.7 \pm 9.03 b c^{*}$ & $81.5 \pm 25.1^{c^{*}}$ \\
\hline
\end{tabular}

a,b: small uppercase letters indicate significant difference $(p<0.05)$ between means of one row. Bold number pairs indicate significant difference $(p<0.05)$ between 5 - and 10-day treatment data. ${ }^{*}$ values above the physiological upper level, 24-49 IU/L for ALT, 4.0-9.3 mmol/L for urea and 31-48 $\mu \mathrm{mol} / \mathrm{L}$ for creatinine according to Boehm et al. [21].

\subsubsection{Enzymes}

The plasma aspartate aminotransferase (AST) and alanine aminotransferase (ALT) activities showed a toxin dose associated increase in both treatments ( 5 and 10 days). Both enzymes reached peak activity values in the 100 ppm treatment.

\subsubsection{Nitrogenous Metabolites}

The plasma total protein concentration was the highest in the 50 ppm group in the 5-day treatment, while in the 10-day study there was no difference among the groups. Albumin showed an identical concentration pattern.

Comparing the 5- and 10-day treatments, total protein was lower in the 50 ppm treatment in the 10-day setting, as compared to the 5-day one (bold data pair).

Plasma creatinine concentration increased in parallel with the increasing mycotoxin dose, the highest plasma concentration was measured in the 100 ppm group, in both treatments. Comparing the exposure time-associated differences, the 10-day treatment induced significantly higher creatinine concentrations, as compared to the 5-day setting in case of $100 \mathrm{ppm}$.

Plasma urea concentration showed gradual increase in both treatments; the lowest concentrations were measured in the control, while in both treatments the 100 ppm treatment was associated with the highest plasma levels.

\subsubsection{Lipids}

After the 5-day treatment total cholesterol concentration was only different (control < FUM) between the control and the 100 ppm groups, while in the 10-day treatment the control was different from all toxin-treated groups. 


\subsubsection{Glucose}

Regarding the plasma glucose level, a reduction was found to be associated with the toxin administration in both treatment periods ( 5 and 10 days). In contrast, the highest level was in the control from the two experiments, the 5-day treatment providing the higher values compared to the 10-day treatment (bold data pair).

\subsubsection{Dose-Dependence of the Plasma Clinical Chemical Compounds}

From the enzymes, nitrogenous compounds and also from the lipids, datasets were tested for dose-dependent responses. The two treatments were handled separately. Table 3 summarizes the variables in which the linear regression model fitting was resulting $R$ square values over 0.8 . AST, ALT, total cholesterol, urea and creatinine were providing well-fitting linear response in accordance with the increasing toxin doses.

Table 3. Linear regression equation parameters in the two treatments.

\begin{tabular}{ccccccc}
\hline \multirow{2}{*}{ Parameters } & \multicolumn{3}{c}{ 5 Days } & \multicolumn{3}{c}{ 10 Days } \\
\cline { 2 - 7 } & Slope & Constant & $\boldsymbol{R}^{\mathbf{2}}$ & Slope & Constant & $\boldsymbol{R}^{\mathbf{2}}$ \\
\hline AST & 154.8 & 11.9 & 0.82 & 290.3 & -140.5 & 0.996 \\
ALT & 55.9 & 7.42 & 0.88 & 69.2 & 17.7 & 0.984 \\
total_chol. & 1.22 & 1.7 & 0.95 & 1.13 & 1.64 & 0.93 \\
urea & 1.19 & 7.58 & 0.93 & 4.44 & 3.04 & 0.86 \\
creatinine & 11.2 & 21.7 & 0.97 & 17 & 13.7 & 0.93 \\
\hline
\end{tabular}

\subsection{Antioxidant and Lipid Peroxidation Parameters}

\subsubsection{Liver}

In the hepatic concentration of reduced glutathione (GSH), conjugated trienes (CT) and conjugated dienes (CD), there was no significant difference among the groups (Table 4). The glutathione peroxidase (GSHPx) activity was the highest in the 50 ppm group after 5 days (being significantly higher as the value in the 10-day setting); a significant difference was only proven between the 20 and $50 \mathrm{ppm}$ groups. The malondialdehyde (MDA) concentration was the lowest in both treatment periods in the control animals, and the highest levels were reached in the 20 ppm groups.

Meanwhile, the increasing mycotoxin concentration did not induce any change in the $\mathrm{CD}$ and CT concentrations, the 10-day treatment led to significantly higher concentrations in the 20 and the 50 ppm groups (5 vs. 10 days).

Table 4. Hepatic antioxidant and oxidation product data of the rats (data are means $\pm \mathrm{SD}$ of 6 individuals/group) (GSH: reduced glutathione, GSHPx: glutathione peroxidase, CD: conjugated dienes, CT: conjugated trienes, MDA: malondialdehyde).

\begin{tabular}{|c|c|c|c|c|c|}
\hline Liver & Days in Treatment & Control & $20 \mathrm{ppm}$ & $50 \mathrm{ppm}$ & $100 \mathrm{ppm}$ \\
\hline \multirow{2}{*}{ GSH (micromol/g) } & 5 & $2.72 \pm 0.76$ & $3.01 \pm 0.41$ & $3.06 \pm 0.71$ & $2.95 \pm 1.15$ \\
\hline & 10 & $3.2 \pm 0.27$ & $4.12 \pm 1.19$ & $3.52 \pm 1$ & $3.98 \pm 1.14$ \\
\hline \multirow{2}{*}{ GSHPx (IU/g prot.) } & 5 & $1.39 \pm 0.31^{\mathrm{ab}}$ & $1.11 \pm 0.1^{\mathrm{a}}$ & $1.82 \pm 0.42^{b}$ & $1.6 \pm 0.36^{\mathrm{ab}}$ \\
\hline & 10 & $1.42 \pm 0.2$ & $2.01 \pm 1.02$ & $1.05 \pm 0.53$ & $1.61 \pm 1.06$ \\
\hline \multirow{2}{*}{ MDA (nmol/g) } & 5 & $55.6 \pm 3.19^{a}$ & $69.9 \pm 4.09^{b}$ & $64.9 \pm 7.57^{\mathrm{ab}}$ & $68.9 \pm 8.52^{b}$ \\
\hline & 10 & $47.3 \pm 14.2^{\mathrm{a}}$ & $74.7 \pm 12.4^{b}$ & $61.5 \pm 13.2^{a b}$ & $63.6 \pm 3.94 \mathrm{ab}$ \\
\hline \multirow{2}{*}{ CD (Abs. $232 \mathrm{~nm})$} & 5 & $0.57 \pm 0.02$ & $0.58 \pm 0.03$ & $0.59 \pm 0.02$ & $0.56 \pm 0.04$ \\
\hline & 10 & $0.6 \pm 0.03$ & $0.62 \pm 0.02$ & $0.63 \pm 0.04$ & $0.64 \pm 0.12$ \\
\hline \multirow{2}{*}{ CT (Abs. 268 nm) } & 5 & $0.22 \pm 0.01$ & $0.21 \pm 0.01$ & $0.22 \pm 0.01$ & $0.21 \pm 0.01$ \\
\hline & 10 & $0.22 \pm 0.01$ & $0.23 \pm 0.01$ & $0.24 \pm 0.01$ & $0.25 \pm 0.07$ \\
\hline
\end{tabular}

a, b: small uppercase letters indicate significant difference $(p<0.05)$ between means of one row. Bold number pairs indicate significant difference $(p<0.05)$ between 5 - and 10 -day treatment data. 


\subsubsection{Kidney}

The renal concentration of GSH was significantly different from the control in the $100 \mathrm{ppm}$ group (5 days). In the 10-day setting all toxin-treated groups provided higher GSH tissue concentrations than the control (Table 5).

Table 5. Kidney, lung and plasma antioxidant and oxidation product data of the rats (GSH: reduced glutathione, GSHPx: glutathione peroxidase, CD: conjugated dienes, CT: conjugated trienes, MDA: malondialdehyde).

\begin{tabular}{|c|c|c|c|c|c|}
\hline Kidney & Days in Treatment & Control & $20 \mathrm{ppm}$ & $50 \mathrm{ppm}$ & 100 ppm \\
\hline \multirow{2}{*}{ GSH (micromol/g) } & 5 & $2.65 \pm 0.44^{\mathrm{a}}$ & $4.26 \pm 1.09^{\mathrm{ab}}$ & $6.65 \pm 0.79^{a b}$ & $5.24 \pm 1.00^{b}$ \\
\hline & 10 & $3.19 \pm 0.47^{a}$ & $4.68 \pm 0.21^{b}$ & $4.86 \pm 0.46^{b}$ & $5.3 \pm 0.61^{b}$ \\
\hline \multirow{2}{*}{ GSHPx (IU/g prot.) } & 5 & $2.47 \pm 0.38^{a b}$ & $1.99 \pm 0.86^{a}$ & $3.13 \pm 0.4^{b}$ & $2.5 \pm 0.33^{a b}$ \\
\hline & 10 & $2.11 \pm 0.1^{\mathrm{a}}$ & $2.89 \pm 0.35^{b}$ & $2.82 \pm 0.18^{b}$ & $2.97 \pm 0.51^{b}$ \\
\hline \multirow{2}{*}{ MDA (nmol/g) } & 5 & $52.2 \pm 8.0^{\mathrm{ab}}$ & $57.7 \pm 5.09^{b}$ & $44.3 \pm 2.89^{a}$ & $63.4 \pm 10.1^{b}$ \\
\hline & 10 & $66.5 \pm 11.3^{b}$ & $55.0 \pm 8.27^{a b}$ & $41.9 \pm 6.24^{\mathrm{a}}$ & $54.8 \pm 9.75^{a b}$ \\
\hline Lung & Days in Treatment & Control & $20 \mathrm{ppm}$ & $50 \mathrm{ppm}$ & $100 \mathrm{ppm}$ \\
\hline \multirow{2}{*}{ GSH (micromol/g) } & 5 & $3.44 \pm 0.39$ & $3.81 \pm 0.54$ & $3.4 \pm 0.37$ & $3.41 \pm 0.33$ \\
\hline & 10 & $3.49 \pm 0.45$ & $3.75 \pm 0.47$ & $2.94 \pm 0.44$ & $3.26 \pm 0.58$ \\
\hline \multirow{2}{*}{ GSHPx (IU/g prot.) } & 5 & $2.97 \pm 0.42$ & $3.26 \pm 0.68$ & $3.16 \pm 0.48$ & $3.06 \pm 0.36$ \\
\hline & 10 & $2.69 \pm 0.29$ & $2.97 \pm 0.63$ & $2.56 \pm 0.27$ & $2.67 \pm 0.48$ \\
\hline \multirow{2}{*}{ MDA (nmol/g) } & 5 & $28.6 \pm 6.54^{\mathrm{ab}}$ & $35.2 \pm 6.67^{b}$ & $24.1 \pm 3.16^{a}$ & $27.7 \pm 4.28^{a b}$ \\
\hline & 10 & $35.3 \pm 4.91^{\mathrm{a}}$ & $55.6 \pm 5.03^{c}$ & $39.1 \pm 2.78^{a b}$ & $42.9 \pm 4.25^{b}$ \\
\hline Plasma & Days in Treatment & Control & $20 \mathrm{ppm}$ & $50 \mathrm{ppm}$ & 100 ppm \\
\hline \multirow{2}{*}{ GSH (micromol/g) } & 5 & $3.34 \pm 0.29 \mathrm{ab}$ & $3.44 \pm 0.34^{b}$ & $2.8 \pm 0.34^{a}$ & $3.45 \pm 0.38^{b}$ \\
\hline & 10 & $3.16 \pm 0.25^{\mathrm{a}}$ & $3.46 \pm 0.29^{a b}$ & $3.32 \pm 0.23 \mathrm{ab}$ & $3.97 \pm 0.83^{b}$ \\
\hline \multirow{2}{*}{ GSHPx (IU/g prot.) } & 5 & $3.02 \pm 0.35^{b}$ & $2.47 \pm 0.17^{a}$ & $2.47 \pm 0.36^{a}$ & $2.57 \pm 0.33^{\mathrm{ab}}$ \\
\hline & 10 & $2.69 \pm 0.25$ & $2.73 \pm 0.19$ & $2.83 \pm 0.29$ & $2.58 \pm 0.34$ \\
\hline \multirow{2}{*}{ MDA (nmol/g) } & 5 & $12.4 \pm 1.43^{\mathrm{a}}$ & $14.1 \pm 1.46^{\mathrm{ab}}$ & $14.5 \pm 1.3^{a b}$ & $15.3 \pm 1.24^{b}$ \\
\hline & 10 & $12.4 \pm 0.91^{\mathrm{a}}$ & $14.5 \pm 1.63^{b}$ & $12.4 \pm 0.6^{a}$ & $16.7 \pm 1.11^{\mathrm{c}}$ \\
\hline
\end{tabular}

a,b: small uppercase letters indicate significant difference $(p<0.05)$ between means of one row. Bold number pairs indicate significant difference $(p<0.05)$ between 5 - and 10-day treatment data.

In the 5- and 10-day treatments, in the case of the kidney, GSH differed between the control and the two 50 ppm groups.

The GSHPx activity showed a decrease in the 20 ppm group in the 5-day study (as compared to the $50 \mathrm{ppm}$ ), while in the 10-day study all toxin treated groups showed higher GSHPx activities, as compared to the control.

GSHPx activity was different between the 5- and 10-day treatments only at the $20 \mathrm{ppm}$ dose.

The renal MDA concentration was the lowest in the $50 \mathrm{ppm}$ group in both treatments; in the 5-day setting this differed from the 20 and the 100 ppm group means, while in the 10-day setting a difference was only proven between the $50 \mathrm{ppm}$ and the control groups.

\subsubsection{Lung}

In the lungs GSH and GSHPx were non-responsive. The only compound providing proven difference among groups was MDA. In the 5-day setting the 20 and the $50 \mathrm{ppm}$ groups differed significantly, but a clear alteration pattern could not be seen. In the 10-day treatment the control differed from the 20 and the 100 ppm groups, with the control providing significantly lower values (Table 5).

The MDA concentration was significantly higher in the 10-day treatment, in all toxin fed groups, as compared to the 5-day treatment. 


\subsubsection{Plasma}

The plasma GSH concentration was not following any trend in the 5-day treatment, while in the 10-day treatment its plasma concentration was the highest in the $100 \mathrm{ppm}$ group. The 5 and 10 days' exposure differed at the $50 \mathrm{ppm}$ level significantly (Table 5).

The plasma GSHPx activity decreased in the 5-day treatment in the 20 and the $50 \mathrm{ppm}$ treatments, 20 ppm showing a difference between the 5- and 10-day protocols as well.

The plasma MDA concentration was the highest in the $100 \mathrm{ppm}$ group (in both treatments, as compared to the control).

\subsection{Genotoxicity}

In both treatments (5 and 10 days) a dose-dependent effect was observed in tail intensity. In the 5-day exposure, a significant difference was observed among the control and the experimental groups whereas no difference was observed among the experimental groups. Similarly, in the 10-day exposure experiment all toxin treated groups differed significantly from the control. Moreover, tail intensity mean score of the $20 \mathrm{ppm}$ group was significantly lower than that of the $100 \mathrm{ppm}$ group. When applying a linear dose-response estimation, the accuracy of the two models was $R^{2}=0.81$ and 0.97 in the 5 and 10 day settings, respectively.

Tail intensity (raw data-not shown) did not exceed 16\% which is considered as low genotoxicity [22].

\subsection{Histopathology}

\subsubsection{Liver}

In animals of different groups and in different, non-systematically classified individuals the vacuolar degeneration of hepatocytes (Figure 1) was observed, along with a blurry pattern of the cytoplasm, in some cases with the disintegration of the cytoplasm, with casual fragmentation of it. In addition, hepatocytes with rounded shape occurred in a spread occurrence pattern; these were seceded from the regular cell organization lining and sometimes underwent necrosis (formation of Councilman bodies, Figure 2). These phenomena were observed in all three, toxin-treated groups (20,50,100 ppm). The occurrence frequency and the severity of these were increasing in parallel with the increasing toxin concentration and the length of exposure (Table 6). The above phenomena were matched with the proliferation of the cells belonging to the mononuclear phagocyte system (MPS) in the liver of animals exposed to 50 and $100 \mathrm{ppm}$, mostly occurring at the sites showing severe degenerative alterations.

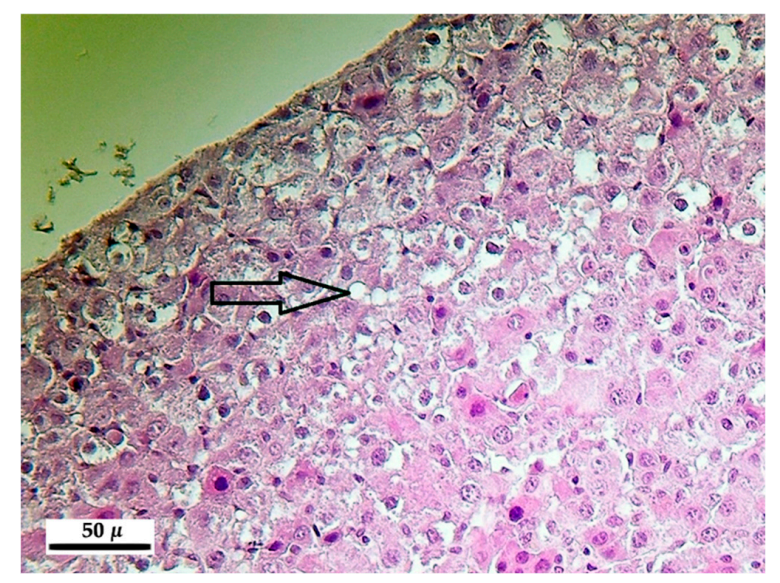

Figure 1. Vacuolar degeneration of the hepatocytes (arrow) after $100 \mathrm{ppm}$ fumonisin $\mathrm{B}_{1}$ exposure in the 10-day experiment (hematoxylin-eosin, $400 \times$ ). 


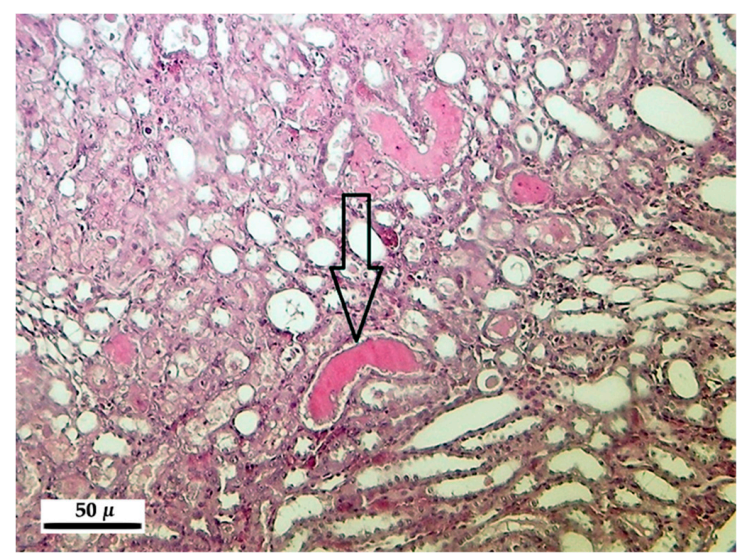

Figure 2. Solitaire necrosis and formation of Councilman bodies (arrow) in the liver of rats after 100 ppm fumonisin $B_{1}$ exposure in the 10-day experiment (hematoxylin-eosin, $400 \times$ ).

Table 6. Time and dose dependent histopathological alterations in the liver, kidney and lung ( $n=6 /$ group).

\begin{tabular}{|c|c|c|c|c|c|c|c|c|c|c|c|c|c|c|c|c|}
\hline \multirow{3}{*}{$\frac{\text { Group (ppm) }}{\text { length of exposure (day) }}$} & \multicolumn{8}{|c|}{$\begin{array}{l}\text { Number of Animals Showing the } \\
\text { Respected Alteration in the } \\
\text { Respective Group ( } n=6 / \text { Group) }\end{array}$} & \multicolumn{8}{|c|}{$\begin{array}{l}\text { Total Score (Representing the Severity of } \\
\text { the Alteration) }{ }^{1}\end{array}$} \\
\hline & \multicolumn{2}{|c|}{$\begin{array}{c}0 \\
\text { (control) }\end{array}$} & \multicolumn{2}{|c|}{20} & \multicolumn{2}{|c|}{50} & \multicolumn{2}{|c|}{100} & \multicolumn{2}{|c|}{0 (control) } & \multicolumn{2}{|c|}{20} & \multicolumn{2}{|c|}{50} & \multicolumn{2}{|c|}{100} \\
\hline & 5 & 10 & 5 & 10 & 5 & 10 & 5 & 10 & 5 & 10 & 5 & 10 & 5 & 10 & 5 & 10 \\
\hline \multicolumn{17}{|c|}{ Liver } \\
\hline Vacuolar degeneration & 0 & 0 & 6 & 6 & 6 & 6 & 6 & 6 & 0 & 0 & 6 & 12 & 9 & 14 & 13 & 16 \\
\hline Cytoplasma fragmentation & 0 & 0 & 4 & 6 & 6 & 6 & 6 & 6 & 0 & 0 & 4 & 6 & 8 & 14 & 12 & 18 \\
\hline Solitaire necrosis (Councilman bodies) & 0 & 0 & 2 & 3 & 4 & 6 & 6 & 6 & 0 & 0 & 2 & 3 & 4 & 12 & 10 & 18 \\
\hline MPS cell proliferation & 0 & 0 & 0 & 0 & 0 & 4 & 3 & 6 & 0 & 0 & 0 & 0 & 0 & 4 & 30 & 12 \\
\hline \multicolumn{17}{|c|}{ Kidney } \\
\hline Tubular degeneration & 0 & 0 & 4 & 6 & 5 & 6 & 6 & 6 & 0 & 0 & 4 & 10 & 6 & 13 & 12 & 17 \\
\hline Tubular necrosis & 0 & 0 & 0 & 0 & 0 & 6 & 1 & 6 & 0 & 0 & 0 & 0 & 0 & 8 & 1 & 12 \\
\hline Detachment of tubular epithelial cells & 0 & 0 & 0 & 0 & 2 & 6 & 6 & 6 & 0 & 0 & 0 & 0 & 2 & 6 & 6 & 12 \\
\hline Tubular dilatation & 0 & 0 & 0 & 0 & 0 & 1 & 0 & 6 & 0 & 0 & 0 & 0 & 0 & 1 & 0 & 15 \\
\hline Hyaline accumulation & 0 & 0 & 0 & 0 & 0 & 0 & 0 & 6 & 0 & 0 & 0 & 0 & 0 & 0 & 0 & 11 \\
\hline \multicolumn{17}{|c|}{ Lung } \\
\hline Any alteration & 0 & 0 & 0 & 0 & 0 & 0 & 0 & 0 & 0 & 0 & 0 & 0 & 0 & 0 & 0 & 0 \\
\hline
\end{tabular}

${ }^{1}$ total score has been calculated as the sum of the individual scores $(n=6)$.

\subsubsection{Kidney}

In rats treated with different toxin concentrations for different time periods, the renal epithelial tubular cells showed degeneration, and in some instances their necrosis or detachment occurred (Figure 3). The slighter, first mentioned modification was characteristic to lower exposure, while the second symptoms were occurring in the 50 and 100 ppm exposed animals. In the group of rats exposed to $100 \mathrm{ppm}$ for 10 days, in well-defined areas, the dilatation of tubule groups was found (Figure 4), sometimes the internal epithelium was atrophic or fully absent; in their lumen, hyalin cones were developed with typical eosinophil stain adsorption. The latter finding refers to the serious damage of the renal excretory function. 


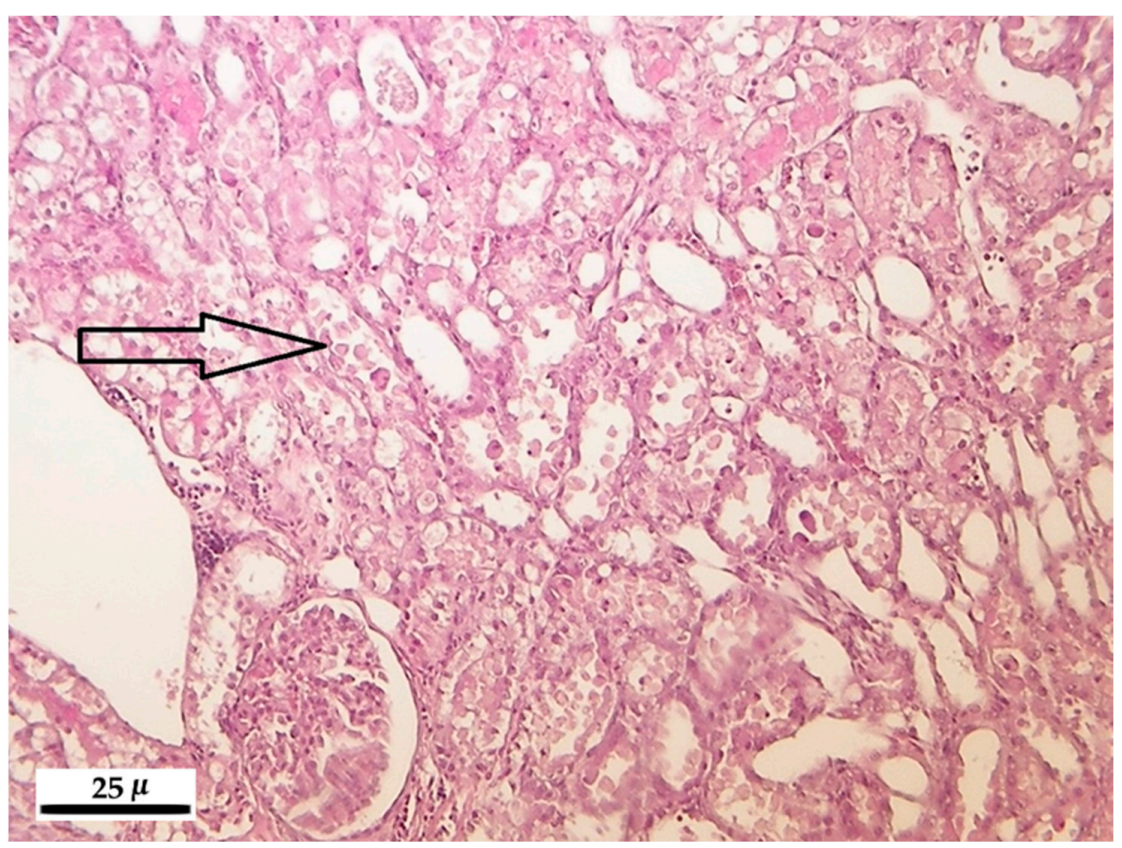

Figure 3. Necrotic and detached tubular epithelial cells in the tubular lumen (arrow) of the kidney after 100 ppm fumonisin $B_{1}$ exposure in the 10-day experiment (hematoxylin-eosin, 200×).

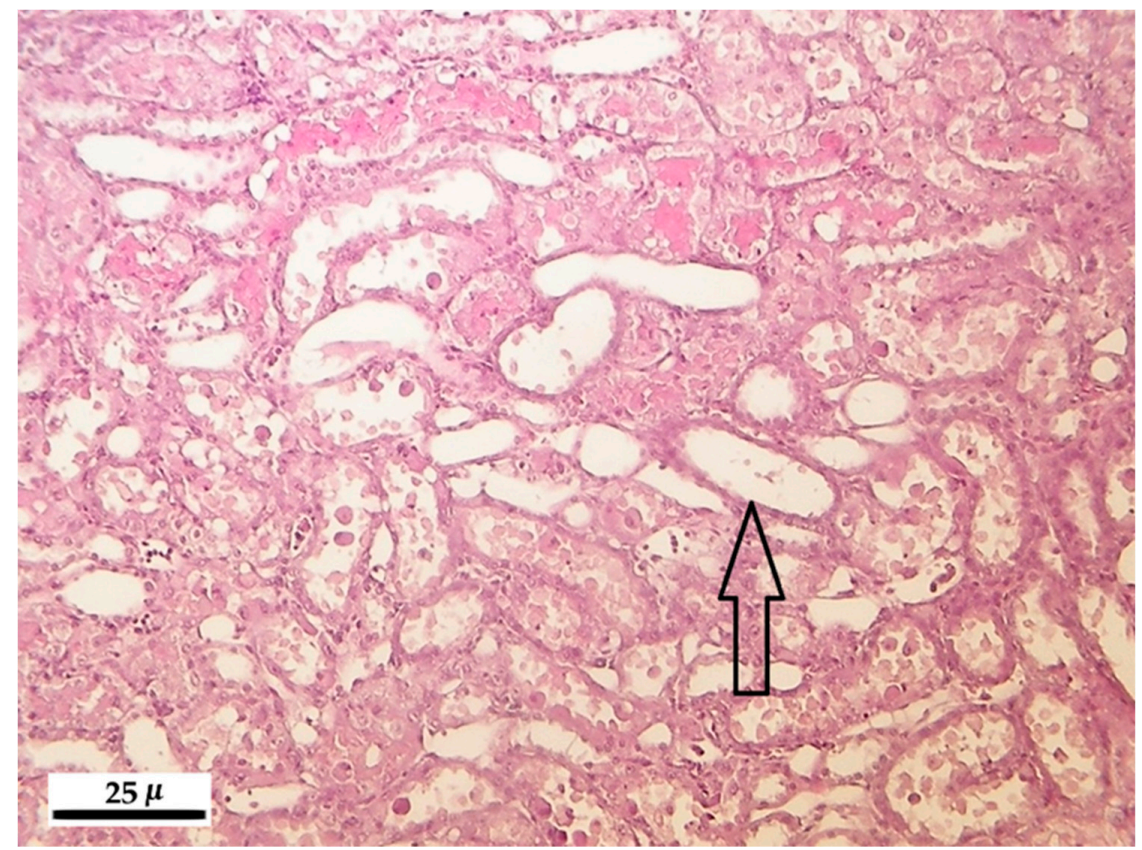

Figure 4. Tubular dilatation (arrow) in the kidney of rats after $100 \mathrm{ppm}$ fumonisin $\mathrm{B}_{1}$ exposure in the 10-day experiment (hematoxylin-eosin, 200×).

\subsubsection{Lung}

Pulmonary oedema or histopathological alteration of the lung was found in none of the animals, irrespective of the treatment.

\section{Discussion}

The main target organ of $\mathrm{FB}_{1}$ toxicity in rats is the kidney, while in mice it is the liver (WHO 2001) [23]. Renal carcinogenicity of $\mathrm{FB}_{1}$ is more pronounced in male rats and liver carcinogenicity in female mice [24]. Accordingly, we tested male rats and analyzed both organs mentioned. 


\subsection{Feed Intake, Body and Organ Weights}

In the study of Bondy et al. [25] body weight and feed intake values decreased as the result of i.p. $\mathrm{FB}_{1}$ treatment $(0.75 \mathrm{mg} / \mathrm{kg}$ BW for 4 and 6 days), similarly to our study. The authors speculated that in their study possible dehydration occurred, since plasma albumin concentration increased. In our study, the increase of albumin level (similarly to total protein) was temporary and was observed only in case of the $50 \mathrm{ppm}$ setting in the 5-day exposure. We also observed polyuria, but data were not recorded, and clinical chemistry results did not support dehydration (concentration of urea and creatinine increased but it could be attributable to the impaired renal function caused by the time- and dose-dependent renal toxicity of $\mathrm{FB}_{1}$ ). Thus, significantly decreased feed intake and hepato- and nephrotoxic effects may be, at least partly, contributors of the BW loss. Hepatic influencement is further supported by the increasing blood total cholesterol levels, in spite of decreasing BW and feed intake [25].

\subsection{Serum Clinical Chemistry}

\subsubsection{Enzymes}

The AST and the ALT activities showed a toxin dose associated increase in both treatment periods. Elevated ALT and AST activity values were similarly observed when purified $\mathrm{FB}_{1}$ was administered i.p. to male Sprague-Dawley rats at 7.5 or $10 \mathrm{mg} / \mathrm{kg}$ body weight/day for 4 consecutive days [26]. Although AST is not merely liver specific, hepatic damage is sensitively and proportionally (in a linear manner, Table 3) indicated by it in case of $\mathrm{FB}_{1}$ toxicosis, irrespective of the length of exposure. Similar results were reported in piglets after 9 days and $1.5 \mathrm{mg} / \mathrm{kg} \mathrm{BW} \mathrm{FB}{ }_{1}$ [27]. However, i.p. results on the clinical chemical composition of rat blood are rare in the literature. If gavage was used, Bondy et al. [28] reported increased ALT activity in the rat serum after $5 \mathrm{mg} \mathrm{FB} / 1 \mathrm{~kg}$ diet/day gavage dose. In one of our related studies, when gavaging rats with a $5 \mathrm{mg} / \mathrm{kg}$ diet $\mathrm{FB}_{1}$, we did not detect any alteration in the aminotransferase activities (Szabó et al. 2018; unpublished dataset), but ALT has been found to play a crucial role in shaping the total group variance, as analyzed by principal component analysis.

\subsubsection{Nitrogenous Metabolites}

The primary toxic effect of $\mathrm{FB}_{1}$ concerns the kidneys in rodents [29], which is mostly relevant in rats. The nephrotoxic effect may be induced even prior detectable hepatotoxicity, when feeding $9 \mathrm{mg} / \mathrm{kg}$ dietary $\mathrm{FB}_{1}$ [29]. Only 234 and $484 \mathrm{mg} / \mathrm{kg}$ dietary $\mathrm{FB}_{1}$ was leading to the degeneration of the renal tubular epithelium in male Fisher rats in the study cited, adding that this was already an apoptotic process. Bondy et al. [30] exposed male rats to 1, 5, 15, 35 or $75 \mathrm{mg} \mathrm{FB} \mathrm{F}_{1} / \mathrm{BW} \mathrm{kg}$ and determined blood urea $\mathrm{N}$, without alterations, while at a direct mycotoxin load intravenously (1.25 mg/BW kg) an increase was found in blood urea [31]. In addition, urinanalysis revealed primarily transient effects [30], with concentration peaks at days $6-8$, and after 12 days values returned to the baseline. It is thus a novel finding that in this study both treatments induced systematical linear dose response for plasma urea, irrespective of the exposure length.

A dose of $15 \mathrm{mg} \mathrm{FB} 1 /$ diet $\mathrm{kg}$ /day induced increased cytoplasmic vacuolation of adrenal cortex cells, indicating that the adrenals are also potential targets of $\mathrm{FB}_{1}$ [25]. When analyzing nephrotoxicity of $\mathrm{FB}_{1}$, Bondy et al. [25] described elevated creatinine concentrations in the experimental rats, as well as higher uric acid levels; former is consonant with our data. In an earlier i.p. study [32], 4 days on $10 \mathrm{mg} /$ diet $\mathrm{kg} \mathrm{FB}_{1}$ dose increased creatinine excretion, but this was paired with minimal histopathological alterations. Our results are generally similar to this, even at the highest $\mathrm{FB}_{1}$ level: no alteration was found of the high molecular weight proteins in the plasma (total protein and albumin), referring to an unaltered glomerular permeability. Although creatinine excretion has already been reported as a non-specific effect of $\mathrm{FB}_{1}$-induced nephrotoxicity, here we newly report as well exposure time dependence, since at $100 \mathrm{ppm}$ at 5 and 10 days it led to significantly different plasma creatinine concentrations (Table 2). 


\subsubsection{Lipids}

After the 5-day treatment total cholesterol concentration was only different between the control and the 100 ppm groups, while in the 10-day treatment the control was different from all toxin-treated groups. Elevated total cholesterol, which is a typical response to $\mathrm{FB}_{1}[27,31]$ was as well observed at $5 \mathrm{mg} \mathrm{FB} 1$ /diet $\mathrm{kg} /$ day and higher in rats [25]. Not only i.p. exposure, but as well different toxin administration types have been found to increase serum total cholesterol (feeding [33]; gavage [30]; single intravenous dose of $1.25 \mathrm{mg} / \mathrm{kg}$ BW [31]). The effect of fumonisin $B_{1}$ on the cholesterol homeostasis may be multi-factorial, since sphingomyelin is a component of circulating lipoproteins and thus has an effect on the cellular cholesterol uptake [34], and ultimately on the cholesterol release of lipoproteins. A new addition to this has been published by Burger et al. [35], reporting that the originally asymmetrical hepatic subcellular (microsomal, mitochondrial and nuclear fractions) membrane loses its integrity as a key result of $\mathrm{FB}_{1}$. Not only are fatty acid metabolism and enzyme activity perturbation induced by $\mathrm{FB}_{1}$, but membrane microdomains are compositionally modified, typically depleted in cholesterol. This overall structural modification of the membrane rafts is coupled with the modification of the signaling mechanism, ultimately shifting the cell regulation towards apoptosis [35].

\subsubsection{Glucose}

The $\mathrm{FB}_{1}$-induced lowering in plasma glucose level is a rare finding. Similar results have only been published for heifers in a 24-week study [36]. The most relevant findings to explain this may be two factors: first, decreasing BW and liver weight, along decreased feed intake, associated with higher $\mathrm{FB}_{1}$ doses, may lower the plasma glucose level. Second, $\mathrm{FB}_{1}$ is a well-known ceramide synthesis inhibitor, and as such, has a pro-apoptotic effect on skeletal muscles [37]. Since lipoapoptosis occurs in skeletal muscle myotubes, at least partially via de novo ceramide accumulation (typical $\mathrm{FB}_{1}$ effect), an inhibiting downstream apoptotic signaling augments glucose uptake, as proven in vitro.

\subsection{Antioxidant and Lipid Peroxidation Parameters}

\subsubsection{Liver}

In the liver, only the ultimate lipid peroxidation product, MDA, increased, but the highest concentration values were attained at the 20 ppm exposure in both treatments. It is known that $\mathrm{FB}_{1}$ increases lipid peroxidation in rat liver and primary rat hepatocytes [38]. It is worth mentioning that in rats the primary target organ of $\mathrm{FB}_{1}$ is the kidney, and this is followed by the liver [39]. Since MDA results from end-phase lipid peroxidation, it seems that hydrogen free radicals attacked tissue lipids, as already published in an earlier study in rats [16]. Interestingly, a lower dose for a longer exposure period (10 ppm for 14 days) failed to induce MDA increment in rabbits [17], referring to a possible dose-dependent effect of $\mathrm{FB}_{1}$ onward in vivo lipid peroxidation. It is rather interesting that initiation-phase lipid peroxidation, as assessed by the determination of conjugated dienes and trienes, was not increased in the liver by any of the treatments. The real physiological background of this phenomenon remains unresolved, since root component (membrane lipid fatty acid) depletion is not a realistic case. Anyway, it is important to note that CD and CT concentrations were significantly higher in the 10-day setting, for both compounds, even though a dose-dependent increase was not present in this study. Summarizing the above findings, either hepatic effect was less pronounced of the hepatic defense was more profound, as compared to the kidney. The results unequivocally support the statement [39] that nephrotoxicity of $\mathrm{FB}_{1}$ is stronger than its hepatotoxic effect, even at high $\mathrm{FB}_{1}$ doses.

Based on the results of Abdellatef and Khalil [40], who applied oral exposure to 0, 50, 100 and $200 \mathrm{mg} \mathrm{FB} 1 / \mathrm{kg}$ diet (equivalent to $0,6,12$ and $24 \mathrm{mg} / \mathrm{kg}$ BW per day, respectively) to male Sprague-Dawley rats for 4 weeks, the lowest observed adverse effect level (LOAEL) for liver and kidney oxidative stress has been declared as $6 \mathrm{mg} / \mathrm{kg} \mathrm{BW} /$ day, which is 50, 20 and 10 times the dose compared to ours $(120,300$ and $600 \mu \mathrm{g} / \mathrm{kg}$ BW/day). 


\subsubsection{Kidney}

GSH (reduced glutathione) is a potent antioxidant, being present in the tissues in relatively high concentrations. When analyzing the kidney, a gradual and significant increase was shown when comparing the control and the $100 \mathrm{ppm}$ treatment. This result seems to be contradictory, since GSH is generally depleted quickly (12-48 $\mathrm{h}$ in rats after a single intravenous dose [31]) by oxidative stimuli

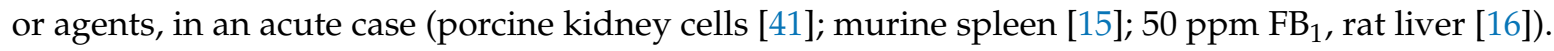
However, its tissue level may as well increase (recover) if the reason is not acute oxidative stress, but an adaptation to prolonged stimulus [31]. When analyzing exposure time-dependence for GSH, there was no systematic difference between the 5 and 10 days settings; there was a defined increase in the tissue GSH concentration, but linear model fitting was not possible. We assume no clearly defined dose-dependent increase of renal cortical GSH concentration, at least not in the time-frame of this study.

Since reduced glutathione is partly regenerated by GSHPx, its increased activity either in tissues (isoform 2) or in plasma (isoform 3) refers to enhanced antioxidant defense capacity of the organism [42]. Thus, both in the 5 and in the 10-days treatments, but most expressed in the latter, GSHPx-aided enzymatic defense was evoked by the mycotoxin treatment in the renal cortex; this defense may be the part background of the enzymatic adaptation. It may be visible that enzymatic adaptation was more serious in the 10-day case, but inter-group difference ( 5 vs. 10 days) was not found. This is consonant with our earlier results, in which 5 days on 50 ppm $\mathrm{FB}_{1}$ was not yet activating the enzymatic antioxidant defense in rats [16].

Moreover, this protective effect may be seen in the concentration of kidney MDA. There was practically no systematic effect of the toxin treatment on the tissue lipid peroxidation end product, thus, marked lipid peroxidation was not proven. We suppose that this result may be as well associated with the exposure in a more complex manner, since $\mathrm{FB}_{1}$ strongly augments free radical production. Interestingly, an opposite result has been published by Domijan et al. [39], where very low $\mathrm{FB}_{1}$ doses (50 and 200 microg/ $\mathrm{kg}$ BW dietary $\mathrm{FB}_{1}$ ) induced renal lipid peroxidation (MDA $\uparrow$ ) after 15 days in rats. Thus, it seems that the effect of $\mathrm{FB}_{1}$ on ROS over-production is a consequence rather than a mechanism of its toxicity.

\subsubsection{Lung}

In the lung, the antioxidant system is very well developed, since lung epithelium is continuously exposed to an inhaled, high concentration of oxygen [43]. Thus, the lung is generally more potent at inhibiting the oxidative attack arising from its function. This has been proven by the full lack of inter-group differences in the GSH concentration and in the GSHPx activity. In contrast, end-phase lipid peroxidation was significantly higher in two (20 and $100 \mathrm{ppm}$ ) intoxicated groups' lungs, as assessed with the tissue MDA concentration in the 10-day treatment. Interestingly, as reported by Petrache et al. [44] ceramide, a second messenger lipid, is a crucial mediator of alveolar, apoptotic destruction and the inhibition of enzymes controlling de novo ceramide synthesis prevents alveolar cell apoptosis and oxidative stress. Our results are likewise opposite. The explanation of this contradiction may be that there exist six isoforms of ceramide synthase, with tissue-specific expression in mammals [27]. The expression and even the level of transcripts of CerS1 and 4 have been published not to decrease, but to increase in the lung as a result of $\mathrm{FB}_{1}$ intoxication of piglets [27]. In the detailed study, the authors prove that lung tissue extract was able to increase stearoyl-dihydrocermide synthesis, adding $\mathrm{FB}_{1}$ can either inhibit or activate dihydroceramide synthesis depending on tissue type and mycotoxin dose.

\subsubsection{Blood Plasma}

Blood plasma provided differential reactions in terms of GSH concentration on the oxidative stress, since in the plasma there is a specific GSH isoform present. Although our analysis was not isoform 
specific, it is visible (Table 5) that the 10-day exposure led a tendentious increase of plasma reduced glutathione concentration, the control and the most strongly toxic treatments providing significant difference. Although GHSPx was not in all cases reactive (no evoked enzymatic defense), the final lipid peroxidation product, MDA provided a very clearly increasing trend, with a higher slope in the 10-day treatment. Domijan et al. [39] reported similar results in the low-dose rat treatment, indicating that the time-demand of the increase of plasma MDA concentration is more than 2 days (ca. 5-7 days). Abel and Gelderblom [38] suggested that lipid peroxidation might be the consequence rather than the cause of the $\mathrm{FB}_{1}$ effect on the cell level; anyhow, at a $250 \mathrm{mg} / \mathrm{kg}$ dietary $\mathrm{FB}_{1}$ level authors described marked hepato- and as well subcellular oxidative damage in rats. The authors demonstrated that addition of alpha-tocopherol to primary hepatocyte cultures completely abolished the $\mathrm{FB}_{1}$-mediated increase in thiobarbituric acid reactive substances, but provided only partial protection from $\mathrm{FB}_{1}$ hepatotoxicity, indicating that lipid peroxidation may occur secondarily to $\mathrm{FB}_{1}$ cytotoxicity. We ultimately suppose that $\mathrm{FB}_{1}$-induced lipid peroxidation is reflected by multiple lipid-associated parameters in the blood plasma: partly by augmented hepatic lipoprotein secretion (increased total cholesterol concentration) and the increase of plasma malondialdehyde levels.

\subsection{Genotoxicity}

Tail intensity (raw data not shown) did not exceed $16 \%$ in any of the treatments, which is considered to be low genotoxicity. This can be attributed to the short exposure period and it is comparable to previous results ([45]; Szabó-Fodor et al., 2018, unpublished observations). To the best of our knowledge there are no studies on the genotoxic effect (DNA damage) of $\mathrm{FB}_{1}$ on peripheral blood lymphocytes of rats. Although $\mathrm{FB}_{1}$ is a possible carcinogen [13], $\mathrm{FB}_{1}$ is considered as non-genotoxic [46]. According to Wang and Groopman [47], fumonisins are the only carcinogenic mycotoxins not having a direct DNA damage-inducing effect. Theumer et al. [48] investigated the genotoxic effect of dietary $\mathrm{FB}_{1}$ (100 mg/kg of feed) on male Wistar rats. Comet assay was used to assess the DNA damage in spleen mononuclear cells isolated from the rats. $\mathrm{FB}_{1}$ induced a very high tail intensity of $81.7 \%$. The high concentration of $\mathrm{FB}_{1}$ in combination with the prolonged exposure (90 days) could account for this high DNA damage. Although generally the extent of DNA damage was low, interestingly, the dose dependence could be characterized by a quasi linear relationship, as shown in Figure 5. The accuracy of fitting was higher in case of the longer treatment, and the scanning electron micrograph (SEM) of the dataset was visibly minor in the higher doses. This refers to a close relationship between dose, exposure time and the extent of damage.
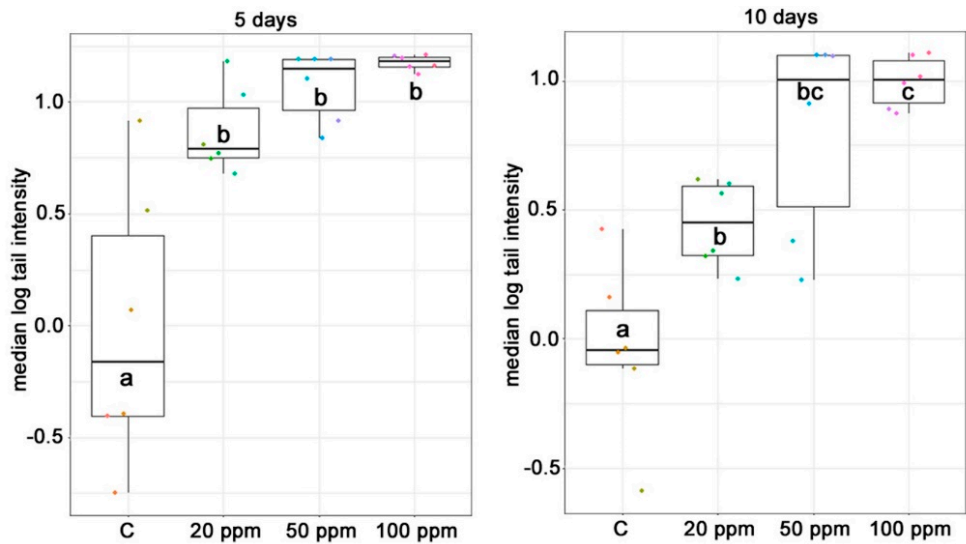

Figure 5. Log tail intensity values (median $\pm \mathrm{SD} ; n=6$ /group) corresponding to DNA damage of lymphocytes after 5 and 10 days of intraperitoneal exposure of animals to increasing concentrations of $\mathrm{FB}_{1}$ (C: control, 20, 50, $100 \mathrm{mg} / \mathrm{kg}$ dietary dose equivalent). 


\subsection{Histopathological Analysis}

\subsubsection{Liver}

Following oral exposure to $\mathrm{FB}_{1}$, early signs of hepatotoxicity in rodents were apoptosis, necrosis, proliferation and regeneration, and hyperplasia of the bile duct. Histopathological alterations reported by Gelderblom et al. [49] in a longer rat-feeding trial of $\mathrm{FB}_{1}\left(26\right.$ months at $\left.50 \mathrm{mg} / \mathrm{kg} \operatorname{diet} \mathrm{FB}_{1}\right)$ appeared rather intense. Gelderblom et al. [49] observed that the liver of the rats killed from 12 months onwards appeared to be distorted and had a nodular appearance and a variegated color due to the presence of fatty changes, necrosis, hemorrhage and an irregular blood supply. In addition, the severity of lesions increased progressively towards the end of the experiment. Our results mostly support the onset of a necrotic process, adding that dose-associated severity has been observed: solitaire necrosis, vacuolar degeneration and cytoplasma fragmentation was more frequent at higher doses.

\subsubsection{Kidney}

The kidney is the major target organ of $\mathrm{FB}_{1}$ in rats, but species-, strain-, and sex-dependent differences in dose response may occur [39]. In both liver and kidney, apoptosis alone or together with increased mitosis is an early microscopic indicator of tissue injury. Cytomegaly, anisocytosis, anisokaryosis, cytoplasmic vacuolation (hepatocellular) and necrosis may as well become evident in both tissues with increasing mycotoxin dose [50]. When purified $\mathrm{FB}_{1}$ was administered i.p. to the male Sprague-Dawley rats at $0.75 \mathrm{mg} / \mathrm{kg}$ BW/day for 2-4-6 consecutive days, Bondy et al. [26] observed minimal renal lesions with infrequent, typically single-cell necrosis, and desquamation of epithelial cells was observed. What we found was mostly the detachment of tubular epithelial cells at $50 \mathrm{ppm}$ and over. This is consonant with findings in Spague-Dawley rats [32], with ezymuria as a result of tubular cell damage, using 7.5-10 mg FB 1 / BW kg intraperitoneally. The tubular degeneration found in our study is in agreement of the results of Suzuki et al. [32], reporting reduced anion transport in $\mathrm{FB}_{1}$-intoxicated rats. This result is further underpinned by the hyalin accumulation in our study, referring to compromised excretory function. Though the dose applied [32] was lower as in our treatment, authors also provided evidence of single cell necrosis at $10 \mathrm{ppm}$, which was not found in our present work. Higher dose (700 vs. $600 \mu \mathrm{g} / \mathrm{kg} \mathrm{BW}$ ) of $\mathrm{FB}_{1}$ (provided as fungal culture in the diet) and longer exposure (42 vs. 10 days) to ours did not affect the creatinine level in plasma, water intake, osmolarity and urinary excretion of sodium, while increased urine volume and potassium excretion and caused mild tubulointerstitial changes in the outer cortex of the kidney [51]. With regard to the histopathological alterations to the kidney in a long exposure, Gelderblom et al. [49] further described atrophic, pale, and the irregular outline and presence of numerous cortical and medullary retention cysts of the kidney.

\subsubsection{Lung}

Pulmonary oedema or any other histopathological alteration of the lung was found in none of the animals, irrespective of the treatment. We conclude that pulmonary influencement was minimal at the exposure applied, meanwhile there exists a robust knowledge on the pulmonary effects of $\mathrm{FB}_{1}$ in pigs, but rats at the present exposure level are likely to be unaffected. The lung was analyzed based on our recent results according to which, during a 5-day $\mathrm{FB}_{1}$ feeding trial (50 ppm) the Hsp70 expression of the rat lung significantly increased by $40 \%$ as compared to the lung tissue of the control rats without significant changes in the antioxidant (GSH, GSHPx) and lipid peroxidation (MDA) parameters [52]. In the study of Salam et al. [53], male rats were fed 10 and $30 \mathrm{mg} / \mathrm{kg} \mathrm{BW} \mathrm{FB} \mathrm{B}_{1}$ in Fusarium culture material for 1, 4 and 8 weeks. Histopathology revealed an effect on the lung in the form of pulmonary congestion and alveolar edema, focal areas of interstitial edema, pulmonary congestion with inflammatory cellular infiltration already after 1 week. The severity and character of these pathological changes showed dose- and time-dependency. 


\section{Conclusions}

Increasing $\mathrm{FB}_{1}$ dose and exposure interval was used to challenge the blood clinical chemical parameters, kidney, liver and lung antioxidant defense and histopathological response in male Wistar rats. We found a linear dose response for AST, ALT, total cholesterol, urea and creatinine in the plasma, and exposure time-dependence for the alteration of the plasma creatinine level. The latter parameter was coupled with marked renal histopathological alterations, tubular degeneration and necrosis, and tubular epithelial cell detachment. The hepatic oxidative stress response was moderate, mostly referring to initial phase lipid peroxidation (CD, CT), and slight functional disturbance (plasma total cholesterol increase). The lung was non-responsive for the treatment, while lymphocyte DNA damage was detectable, but moderate, supporting mild genotoxic effect of $\mathrm{FB}_{1}$.

\section{Materials and Methods}

\subsection{Animals and Feeding}

Adult, male Wistar Crl:WI BR rats (8 weeks of age at the beginning) were enrolled in the study and were kept in metabolic cages (Tecniplast, Castronno, Italy) individually. The animals ( $n=6$ /group, total $n=48$ ) were fed Ssniff $\mathrm{R} / \mathrm{M}-\mathrm{Z}+\mathrm{H}$ feed (Ssniff $\mathrm{GmbH}$, Soest, Germany). The rats were kept in a $12 \mathrm{~h}$ light and $12 \mathrm{~h}$ dark daily rhythm, at $20^{\circ} \mathrm{C}$ in a rodent room, with a relative air humidity of $50 \%$. Feed was offered ad libitum, and feed intake was measured daily.

Increasing concentrations of $\mathrm{FB}_{1}(0,20,50$ and $100 \mathrm{mg} / \mathrm{kg}$ diet, expressed as feed dose equivalent and referred to as ppm in the entire text and tables) were tested in a short- and thereafter a long-term experiment ( 5 and 10 days, respectively), to assess dose and time associated toxic effects. The pure mycotoxin was purchased from Sigma-Aldrich (Schnelldorf, Germany), and stock solutions were prepared with sterile physiological salt solution. The solutions contained the daily toxin dose in exactly $1 \mathrm{~mL}$, and this solution was administered as a single intraperitoneal dose. For the control animals (C), $1 \mathrm{~mL}$ of sterile physiological salt solution was dosed.

Mycotoxin treatment was set as follows: $36 \mu \mathrm{g} /$ animal/day (approx. $120 \mu \mathrm{g} / \mathrm{kg} \mathrm{BW} /$ day), $90 \mu \mathrm{g} / \mathrm{animal} /$ day (approx. $300 \mu \mathrm{g} / \mathrm{kg} \mathrm{BW} /$ day) and $180 \mu \mathrm{g} / \mathrm{animal} /$ day (approx. $600 \mu \mathrm{g} / \mathrm{kg}$ $\mathrm{bw} /$ day). Calculating with the average feed intake of $30 \mathrm{~g} / \mathrm{animal} /$ day and the absorption ratio of the toxin [54], the intraperitoneal (i.p.) administration represented the following dietary exposures: approx. 20,50 and $100 \mathrm{mg} / \mathrm{kg}$ dietary equivalent for $\mathrm{FB}_{1}$.

The two, basically similar treatments lasted for $5(n=24)$ and 10 days $(n=24)$, respectively, only the exposure time being different. On days 6 and 11, after taking blood from the retro-orbital plexus, the animals were sacrificed by cervical dislocation and were immediately dissected.

\subsection{Ethical Permission}

The experimental protocol was authorized by the Food Chain Safety and Animal Health Directorate of the Somogy County Agricultural Office (Hungary), under the permission number SOI/31/00308-10/2017 (date of approval: 27 March 2017).

\subsection{Clinical Chemical Parameters}

The plasma total protein, albumin, creatinine, glucose, urea and the total cholesterol concentrations and the activity of aspartate aminotransferase (AST), alanine aminotransferase (ALT) were determined in a veterinary laboratory (Vet-Med Laboratory, Budapest, Hungary), using Roche Hitachi 917 Chemistry Analyzer (Hitachi, Tokyo, Japan) with commercial diagnostic kits (Diagnosticum LTD., Budapest, Hungary). 


\subsection{Antioxidant Status and Lipid Peroxidation}

For the determination of lipid peroxidation, the samples of blood plasma, liver, kidney and lung were stored at $-70{ }^{\circ} \mathrm{C}$ until analysis. Lipid peroxidation was determined by the quantification of malondialdehyde (MDA) levels with 2-thiobarbituric acid method in blood plasma and organ homogenates [55], and determination of conjugated dienes (CD) and trienes (CT) according to the AOAC [56] method in the liver. The tissue concentration of reduced glutathione (GSH) was measured by the method of Sedlak and Lindsay [57] and the activity of glutathione peroxidase (GSPHx) according to Lawrence and Burk [58].

\subsection{Comet Assay of Lymphocytes}

$50 \mu \mathrm{L}$ heparinized blood was added to $1 \mathrm{~mL} 1 \%$ low melting agarose gel in Eppendorf tubes on $37^{\circ} \mathrm{C}$. The suspension was mixed gently and two drops $(140 \mu \mathrm{L})$ were transferred to slides previously coated with $1 \%$ normal melting point agarose. The slides were covered with cover slips and allowed to set. The cover slips were then removed and cell membranes were lysed with lysis buffer solution ( $1 \%$ Triton X-100, 2.5M NaCl, $10 \mathrm{mM}$ Tris, $0.1 \mathrm{M}$ EDTA, pH10) for $1 \mathrm{~h}$ at $4{ }^{\circ} \mathrm{C}$. Following the lysis the slides were placed in alkaline electrophoresis buffer $(\mathrm{pH} 13)$ in an electrophoresis tank (Cleaver Scientific Ltd., Warwickshire, UK) for $40 \mathrm{~min}$ at $4{ }^{\circ} \mathrm{C}$, followed by electrophoresis at $25 \mathrm{~V}(300 \mathrm{~mA})$ for $30 \mathrm{~min}$ at $4{ }^{\circ} \mathrm{C}$. The slides were then placed in neutralizing buffer ( $\mathrm{pH}$ 7.5) and washed three times for $5 \mathrm{~min}$, followed by a final wash in double distilled water for a further $5 \mathrm{~min}$. The slides were then left to dry overnight and stained with ethidium bromide $(30 \mu \mathrm{L})$ and covered with cover slips.

Tail intensity (TI, \% DNA in the tail) was determined with an epifluorescent microscope (B600 TiFL; optimum filter 4 and $\lambda=302 \mathrm{~nm}$ ) and Comet IV (version 4.3.1.) software (Perceptive Instruments Ltd., Bury St. Edmunds, UK), examining 50 comets per gel, 2 gels per slide, 1 slide per animal. A TI of zero corresponds to a cell with no DNA damage; increasing positive values of TI correspond to greater DNA damage to the respective cells.

\subsection{Histopathological Analysis}

After registering the macroscopic pathological signs on the internal and external organs, the liver, kidneys, lung and spleen were stored in 10\% neutrally buffered formalin and were embedded into paraffin. For light microscopic analysis, microtome slides of 5 micron $(\mu)$ were prepared and stained with hematoxylin-eosin.

The main pathological alterations have been described and scored according their extent and severity as follows: $0=$ no alteration, $1=$ slight $/ \mathrm{small}$ scale $/ \mathrm{few}, 2=$ medium degree $/$ medium scale/medium number, 3 = pronounced/extensive/numerous.

The histopathological analysis was performed according to the Act \#2011 (03.30) of the Hungarian Ministry of Agriculture and Rural Development and was in accordance with the ethical guidelines of the Organization for Economic Cooperation and Development (OECD) Good Laboratory Practice for Chemicals [59].

\subsection{Statistical Analysis}

Statistical analyses were performed using IBM SPSS 20.0 software (IBM Corp., Armonk, NY, USA) [60]. Data processing and the mathematical-statistical calculations were performed using the Compare Means (Independent-Samples-t-test) and Descriptive Statistics modules. Linear regression model was used to test dose dependent fitting in case of the blood biochemical parameters. Data were compared to reference range values for rats [21].

In the case of the comet assay, the experimental unit of exposure was the animal and statistical analysis was based on the individual animal response data. The constant of 0.001 was added to each TI before taking logarithms. The median values of 50 cells were calculated, and the average of the two 
medians (representing one gel = one animal) was used in the general linear model of one-way analysis of variance (ANOVA) as suggested by Bright et al. [61].

In the statistical analyses, differences between groups were considered significant when $p$ values were $<0.05$.

Author Contributions: A.S., M.K. (Melinda Kovács) and J.S.-F. conceived the study design, collected and analyzed data, and wrote the manuscript; M.K. (Mariam Kachlek) performed the genotoxicity analysis and evaluation; M.M. and K.B. analyzed the antioxidant status; R.G. led the histopathological work. O.A. was involved in sample preparation and corrected the manuscript. Y.Y.Z. pericipated largely in the mycotoxigolocial treatment and all samplings.

Funding: This research was funded by the Ministry of Innovation and Technology [GINOP-2.3.2-15-2016-00046] and the Ministry of Human Resources [EFOP-3.6.3-VEKOP-16-2017-00008]. The APC was funded by Hungarian Academy of Sciences [MTA-KE-SZIE 13003].

Acknowledgments: The work was supported by the project GINOP-2.3.2-15-2016-00046 and the EFOP-3.6.3-VEKOP-16-2017-00008 programs.

Conflicts of Interest: The authors declare no conflict of interest.

\section{References}

1. Rheeder, J.P.; Marasas, W.F.O.; Vismer, H.F. Production of fumonisin analogs by Fusarium species. Appl. Environ. Microbiol. 2002, 68, 2101-2105. [CrossRef] [PubMed]

2. European Commission (2003) Updated opinion of the Scientific Committee on Food (SCF) on Fumonisin B1, BIOMIN Mycotoxin Survey, (2017): BIOMIN Holding GmbH, Getzersdorf, Austria. Available online: https://info.biomin.net/acton/attachment/14109/f-0463/1/-/-/1-0009/1-0009/MAG_ MTXsurveyReport_2016_EN_0117_PKO.pdf (accessed on 12 October 2018.).

3. Kubena, L.; Edrington, T.; Harvey, R.; Buckley, S.; Phillips, T.; Rottinghaus, G.; Casper, H. Individual and combined effects of fumonisin $\mathrm{B}_{1}$ present in Fusarium moniliforme culture material and T-2 toxin or deoxynivalenol in broiler chicks. Poult. Sci. 1997, 76, 1239-1247. [CrossRef] [PubMed]

4. Månsson, M.; Klejnstrup, M.L.; Phipps, R.K.; Nielsen, K.F.; Frisvad, J.C.; Gotfredsen, C.H.; Larsen, T.O. Isolation and NMR characterization of fumonisin $\mathrm{B}_{2}$ and a new fumonisin $\mathrm{B}_{6}$ from Aspergillus niger. J. Agric. Food Chem. 2010, 58, 949-953. [CrossRef] [PubMed]

5. Candlish, A.; Aidoo, K.; Smith, J.; Pearson, S. A limited survey of aflatoxins and fumonisins in retail maizebased products in the UK using immunoassay detection. Mycotoxin Res. 2000, 16, 2-8. [CrossRef] [PubMed]

6. D'Arco, G.; Fernández-Franzón, M.; Font, G.; Damiani, P.; Mañes, J. Survey of fumonisins $B_{1}, B_{2}$ and $B_{3}$ in conventional and organic retail corn products in Spain and Italy and estimated dietary exposure. Food Addit. Contam. Part B Surveill. 2009, 2, 146-153. [CrossRef] [PubMed]

7. Cano-Sancho, G.; Ramos, A.J.; Marín, S.; Sanchis, V. Occurrence of fumonisins in Catalonia (Spain) and an exposure assessment of specific population groups. Food Addit. Contam. Part A. Chem. Anal. Control. Expo. Risk Assess. 2012, 29, 799-808. [CrossRef] [PubMed]

8. Jakšić, S.; Abramović, B.; Jajić, I.; Baloš, M.Ž.; Mihaljev, Ž.; Despotović, V.; Šojić, D. Co-occurrence of fumonisins and deoxynivalenol in wheat and maize harvested in Serbia. Bull. Environ. Contam. Toxicol. 2012, 89, 615-619. [CrossRef] [PubMed]

9. Christofidou, M.; Kafouris, D.; Christodoulou, M.; Stefani, D.; Christoforou, E.; Nafti, G.; Christou, E.; Aletrari, M.; Ioannou-Kakouri, E. Occurrence, surveillance, and control of mycotoxins in food in Cyprus for the years 2004-2013. Food Agric. Immunol. 2015, 26, 880-895. [CrossRef]

10. Marasas, W.F.; Kellerman, T.S.; Gelderblom, W.C.; Coetzer, J.A.; Thiel, P.G.; van der Lugt, J.J. Leukoencephalomalacia in a horse induced by fumonisin $\mathrm{B}_{1}$ isolated from Fusarium moniliforme. Onderstepoort J. Vet. Res. 1988, 55, 197-203. [PubMed]

11. Colvin, B.M.; Harrison, L.R. Fumonisin-induced pulmonary edema and hydrothorax in swine. Mycopathologia 1992, 117, 79-82. [CrossRef] [PubMed]

12. Gelderblom, W.C.; Cawood, M.E.; Snyman, S.D.; Marasas, W.F. Fumonisin $B_{1}$ dosimetry in relation to cancer initiation in rat liver. Carcinogenesis 1994, 15, 209-214. [CrossRef] [PubMed] 
13. IARC (International Agency for Research on Cancer). Monographs on the Evaluation of Carcinogenic Risks to Humans No 82; IARC Press: Lyon, France, 2002; pp. 275-366.

14. Wang, E.; Norred, W.P.; Bacon, C.W.; Riley, R.T.; Merrill, A.H. Inhibition of sphingolipid biosynthesis by fumonisins. Implications for diseases associated with Fusarium moniliforme. J. Biol. Chem. 1991, 266, 14486-14490. [PubMed]

15. Abbès, S.; Ben Salah-Abbès, J.; Jebali, R.; Younes, R.B.; Oueslati, R. Interaction of aflatoxin $B_{1}$ and fumonisin $\mathrm{B}_{1}$ in mice causes immunotoxicity and oxidative stress: Possible protective role using lactic acid bacteria. J. Immunotoxicol. 2016, 13, 46-54. [CrossRef] [PubMed]

16. Szabó, A.; Szabó-Fodor, J.; Fébel, H.; Mézes, M.; Repa, I.; Kovács, M. Acute hepatic effects of low-dose fumonisin B(1) in rats. Acta Vet. Hung. 2016, 64, 436-448. [CrossRef] [PubMed]

17. Szabó, A.; Szabó-Fodor, J.; Fébel, H.; Mézes, M.; Bajzik, G.; Kovács, M. Oral administration of fumonisin $B_{1}$ and T-2 individually and in combination affects hepatic total and mitochondrial membrane lipid profile of rabbits. Physiol. Int. 2016, 103, 321-333. [CrossRef] [PubMed]

18. Riedel, S.; Abel, S.; Burger, H.-M.; van der Westhuizen, L.; Swanevelder, S.; Gelderblom, W.C.A. Differential modulation of the lipid metabolism as a model for cellular resistance to fumonisin $\mathrm{B}_{1}$-induced cytotoxic effects in vitro. Prostaglandins. Leukot. Essent. Fatty Acids 2016, 109, 39-51. [CrossRef] [PubMed]

19. Mary, V.S.; Theumer, M.G.; Arias, S.L.; Rubinstein, H.R. Reactive oxygen species sources and biomolecular oxidative damage induced by aflatoxin $\mathrm{B}_{1}$ and fumonisin $\mathrm{B}_{1}$ in rat spleen mononuclear cells. Toxicology 2012, 302, 299-307. [CrossRef] [PubMed]

20. Wang, X.; Wu, Q.; Wan, D.; Liu, Q.; Chen, D.; Liu, Z.; Martínez-Larrañaga, M.R.; Martínez, M.A.; Anadón, A.; Yuan, Z. Fumonisins: Oxidative stress-mediated toxicity and metabolism in vivo and in vitro. Arch. Toxicol. 2016, 90, 81-101. [CrossRef] [PubMed]

21. Boehm, O.; Zur, B.; Koch, A.; Tran, N.; Freyenhagen, R.; Hartmann, M.; Zacharowski, K. Clinical chemistry reference database for Wistar rats and C57/BL6 mice. Biol. Chem. 2007, 388, 1255-1256. [CrossRef] [PubMed]

22. Garcia, O.; Romero, I.; González, J.E.; Mandina, T. Measurements of DNA damage on silver stained comets using free Internet software. Mutat. Res. 2007, 627, 186-190. [CrossRef] [PubMed]

23. WHO. Safety Evaluation of Certain Mycotoxins in Food; IPCS: Geneva, Switzerland, 2001; Volume 47.

24. NTP Technical Report on the Toxicology and Carcinogenesis Studies of Fumonisin B1 (CAS No. 116355-83-0) in F344/N Rats and B6C3F1 Mice (Feed Studies); US Department of Health and Human Service, National Toxicology Program: Research Triangle Park, NC, USA, 1999.

25. Bondy, G.S.; Barker, M.G.; Lombaert, G.A.; Armstrong, C.L.; Fernie, S.M.; Gurofsky, S.; Huzel, V.; Savard, M.E.; Curran, I.H. A comparison of clinical, histopathological and cell-cycle markers in rats receiving the fungal toxins fumonisin $B_{1}$ or fumonisin $B_{2}$ by intraperitoneal injection. Food Chem. Toxicol. 2000, 38, 873-886. [CrossRef]

26. Bondy, G.; Suzuki, C.; Barker, M.; Armstrong, C.; Fernie, S.; Hierlihy, L.; Rowsell, P.; Mueller, R. Toxicity of fumonisin $B_{1}$ administered intraperitoneally to male Sprague-Dawley rats. Food Chem. Toxicol. 1995, 33, 653-665. [CrossRef]

27. Loiseau, N.; Polizzi, A.; Dupuy, A.; Therville, N.; Rakotonirainy, M.; Loy, J.; Viadere, J.-L.; Cossalter, A.-M.; Bailly, J.-D.; Puel, O.; et al. New insights into the organ-specific adverse effects of fumonisin $\mathrm{B}_{1}$ : Comparison between lung and liver. Arch. Toxicol. 2015, 89, 1619-1629. [CrossRef] [PubMed]

28. Bondy, G.S.; Suzuki, C.A.; Mueller, R.W.; Fernie, S.M.; Armstrong, C.L.; Hierlihy, S.L.; Savard, M.E.; Barker, M.G. Gavage administration of the fungal toxin fumonisin $B_{1}$ to female Sprague-Dawley rats. J. Toxicol. Environ. Health. A 1998, 53, 135-151. [PubMed]

29. Bucci, T.J.; Howard, P.C.; Tolleson, W.H.; Laborde, J.B.; Hansen, D.K. Renal Effects of Fumonisin Mycotoxins in Animals. Toxicol. Pathol. 1998, 26, 160-164. [CrossRef] [PubMed]

30. Bondy, G.; Barker, M.; Mueller, R.; Fernie, S.; Miller, J.D.; Armstrong, C.; Hierlihy, S.L.; Rowsell, P.; Suzuki, C. Fumonisin $\mathrm{B}_{1}$ toxicity in male Sprague-Dawley rats. Adv. Exp. Med. Biol. 1996, 392, 251-264. [PubMed]

31. Lim, C.W.; Parker, H.M.; Vesonder, R.F.; Haschek, W.M. Intravenous fumonisin $B_{1}$ induces cell proliferation and apoptosis in the rat. Nat. Toxins 1996, 4, 34-41. [CrossRef] [PubMed]

32. Suzuki, C.A.M.; Hierlihy, L.; Barker, M.; Curran, I.; Mueller, R.; Bondy, G.S. The Effects of Fumonisin B ${ }_{1}$ on Several Markers of Nephrotoxicity in Rats. Toxicol. Appl. Pharmacol. 1995, 133, 207-214. [CrossRef] [PubMed]

33. Voss, K.A.; Chamberlain, W.J.; Bacon, C.W.; Norred, W.P. A preliminary investigation on renal and hepatic toxicity in rats fed purified fumonisin $B_{1}$. Nat. Toxins 1993, 1, 222-228. [CrossRef] [PubMed] 
34. Vance, D.E.; Vance, J.E. Biochemistry of Lipids, Lipoproteins and Membranes; Elsevier: Amsterdam, The Netherlands, 2008; ISBN 9780080559889.

35. Burger, H.M.; Abel, S.; Gelderblom, W.C.A. Modulation of key lipid raft constituents in primary rat hepatocytes by fumonisin $\mathrm{B}_{1}$-Implications for cancer promotion in the liver. Food Chem. Toxicol. 2018, 115, 34-41. [CrossRef] [PubMed]

36. Abeni, F.; Migliorati, L.; Terzano, G.M.; Capelletti, M.; Gallo, A.; Masoero, F.; Pirlo, G. Effects of two different blends of naturally mycotoxin-contaminated maize meal on growth and metabolic profile in replacement heifers. Animal 2014, 8, 1667-1676. [CrossRef] [PubMed]

37. Turpin, S.M.; Lancaster, G.I.; Darby, I.; Febbraio, M.A.; Watt, M.J. Apoptosis in skeletal muscle myotubes is induced by ceramides and is positively related to insulin resistance. Am. J. Physiol. Metab. 2006, 291, E1341-E1350. [CrossRef] [PubMed]

38. Abel, S.; Gelderblom, W.C. Oxidative damage and fumonisin $B_{1}$-induced toxicity in primary rat hepatocytes and rat liver in vivo. Toxicology 1998, 131, 121-131. [CrossRef]

39. Domijan, A.-M.; Peraica, M.; Vrdoljak, A.L.; Radić, B.; Žlender, V.; Fuchs, R. The involvement of oxidative stress in ochratoxin A and fumonisin $\mathrm{B}_{1}$ toxicity in rats. Mol. Nutr. Food Res. 2007, 51, 1147-1151. [CrossRef] [PubMed]

40. Abdellatef, A.A.; Khalil, A.A. Ameliorated effects of Lactobacillus delbrueckii subsp. lactis DSM 20076 and Pediococcus acidilactici NNRL B-5627 on Fumonisin B 1 -induced Hepatotoxicity and Nephrotoxicity in rats. Asian J. Pharm. Sci. 2016, 11, 326-336. [CrossRef]

41. Kang, Y.J.; Alexander, J.M. Alterations of the glutathione redox cycle status in fumonisin $\mathrm{B}_{1}$-treated pig kidney cells. J. Biochem. Toxicol. 1996, 11, 121-126. [CrossRef]

42. Coles, B.F.; Kadlubar, F.F. Human alpha class glutathione S-transferases: Genetic polymorphism, expression, and susceptibility to disease. Methods Enzymol. 2005, 401, 9-42. [CrossRef] [PubMed]

43. Matsuo, M.; Gomi, F.; Dooley, M.M. Age-related alterations in antioxidant capacity and lipid peroxidation in brain, liver, and lung homogenates of normal and vitamin E-deficient rats. Mech. Ageing Dev. 1992, 64, 273-292. [CrossRef]

44. Petrache, I.; Natarajan, V.; Zhen, L.; Medler, T.R.; Richter, A.T.; Cho, C.; Hubbard, W.C.; Berdyshev, E.V.; Tuder, R.M. Ceramide upregulation causes pulmonary cell apoptosis and emphysema-like disease in mice. Nat. Med. 2005, 11, 491-498. [CrossRef] [PubMed]

45. Hafner, D.; Szabó, A.; D’Costa, L.; Szabó-Fodor, J.; Tornyos, G.; Blochné Bodnár, Z.; Ölbeiné Horvatovich, K.; Baloghné Zándoki, E.; Bóta, B.; Kovács, M. Individual and combined effects of feed artificially contaminated with with fumonisin $B_{1}$ and T-2 toxin in weaned rabbits. World Mycotoxin J. 2016, 9, 613-622. [CrossRef]

46. Dragan, Y.P.; Bidlack, W.R.; Cohen, S.M.; Goldsworthy, T.L.; Hard, G.C.; Howard, P.C.; Riley, R.T.; Voss, K.A. Implications of apoptosis for toxicity, carcinogenicity, and risk assessment: Fumonisin $\mathrm{B}(1)$ as an example. Toxicol. Sci. 2001, 61, 6-17. [CrossRef] [PubMed]

47. Wang, J.S.; Groopman, J.D. DNA damage by mycotoxins. Mutat. Res. 1999, 424, 167-181. [CrossRef]

48. Theumer, M.G.; Cánepa, M.C.; López, A.G.; Mary, V.S.; Dambolena, J.S.; Rubinstein, H.R. Subchronic mycotoxicoses in Wistar rats: Assessment of the in vivo and in vitro genotoxicity induced by fumonisins and aflatoxin $B_{1}$, and oxidative stress biomarkers status. Toxicology 2010, 268, 104-110. [CrossRef] [PubMed]

49. Gelderblom, W.C.; Kriek, N.P.; Marasas, W.F.; Thiel, P.G. Toxicity and carcinogenicity of the Fusarium moniliforme metabolite, fumonisin $B_{1}$, in rats. Carcinogenesis 1991, 12, 1247-1251. [CrossRef] [PubMed]

50. Voss, K.A.; Smith, G.W.; Haschek, W.M. Fumonisins: Toxicokinetics, mechanism of action and toxicity. Anim. Feed Sci. Technol. 2007, 137, 299-325. [CrossRef]

51. Venancio, J.C.; Emerich, S.S.; Branquinho, N.T.D.; de Sousa, F.C.; Natali, M.R.M.; Baroni, E.A. Effect of administering a diet contamined with fumonisins on the kidneys of wistar rats. Acta Sci. Biol. Sci. 2014, 36, 333. [CrossRef]

52. Kócsó, D.J.; Szabó-Fodor, J.; Mézes, M.; Balogh, K.; Ferenczi, S.; Szabó, A.; Bóta, B.; Kovács, M. Fumonisin B 1 exposure increases Hsp70 expression in the lung and kidney of rats without inducing significant oxidative stress. Acta Vet. Hung. 2018, 66, 394-407. [CrossRef] [PubMed]

53. Salam, G.A.; Mehlab, E.; Shishtawy, M. Fumonisin Lung Toxicity: Gross and microscopic changes are dose and time dependent. J. Am. Sci. 2012, 8, 729-736. 
54. Martinez-Larranaga, M.R.; Anadon, A.; Diaz, M.J.; Fernandez-Cruz, M.L.; Martinez, M.A.; Frejo, M.T.; Martinez, M.; Fernandez, R.; Anton, R.M.; Morales, M.E.; et al. Toxicokinetics and oral bioavailability of fumonisin $\mathrm{B}_{1}$. Vet. Hum. Toxicol. 1999, 41, 357-362. [PubMed]

55. Botsoglou, N.A.; Fletouris, D.J.; Papageorgiou, G.E.; Vassilopoulos, V.N.; Mantis, A.J.; Trakatellis, A.G. Rapid, Sensitive, and Specific Thiobarbituric Acid Method for Measuring Lipid Peroxidation in Animal Tissue, Food, and Feedstuff Samples. J. Agric. Food Chem. 1994, 42, 1931-1937. [CrossRef]

56. AOAC. Association of Official Analytical Chemists: Arlington, 14th ed.; AOAC: Arlington, VA, USA, 1984.

57. Sedlak, J.; Lindsay, R.H. Estimation of total, protein-bound, and nonprotein sulfhydryl groups in tissue with Ellman's reagent. Anal. Biochem. 1968, 25, 192-205. [CrossRef]

58. Lawrence, R.A.; Burk, R.F. Species, tissues and subcellular distribution of non-selenium dependent glutathione peroxidase activity. J. Nutr. 1978, 108, 211-215. [CrossRef] [PubMed]

59. OECD Environmental Health and Safety Publications. OECD Principles of Good Laboratory Practice (as Revised in 1997). Available online: https://ntp.niehs.nih.gov/iccvam/suppdocs/feddocs/oecd/oecd_ glpcm.pdf (accessed on 12 October 2018.).

60. SPSS. SPSS for Windows ver. 20; SPSS: Chicago, IL, USA, 2012.

61. Bright, J.; Aylott, M.; Bate, S.; Geys, H.; Jarvis, P.; Saul, J.; Vonk, R. Recommendations on the statistical analysis of the Comet assay. Pharm. Stat. 2011, 10, 485-493. [CrossRef] [PubMed]

(C) 2018 by the authors. Licensee MDPI, Basel, Switzerland. This article is an open access article distributed under the terms and conditions of the Creative Commons Attribution (CC BY) license (http://creativecommons.org/licenses/by/4.0/). 